\title{
Exploring Student Self-Plagiarism
}

\author{
Colleen M. Halupa ${ }^{1}$ \\ ${ }^{1}$ Center for Innovation in Teaching and Learning, LeTourneau University, Longview, TX, USA \\ ${ }^{1}$ School of Health Management, A.T.Still University, Kirksville. MO, USA \\ Correspondence: Colleen Halupa, LeTourneau University, Longview, TX, 75602, U.S.A. Tel: 1-903-233-4071. \\ E-mail: colleenhalupa@letu.edu
}

Received: January 5, 2014

Accepted: January 28, 2014

Online Published: February 10, 2014

doi:10.5430/ijhe.v3n1p121

URL: http://dx.doi.org/10.5430/ijhe.v3n1p121

\begin{abstract}
Student self-plagiarism is a confusing issue for both faculty and students alike. This problem is compounded because both groups perceive the concept very differently. Recent literature regarding these perceptions is reviewed and some brief preliminary results of an exploratory multi-university study of student perceptions of self-plagiarism are presented. Key findings in these preliminary results are compared to a previous study at the same universities which measured faculty perceptions towards self-plagiarism. Approximately $60 \%$ of both faculty and students do not truly understand self-plagiarism. In addition, almost $60 \%$ of students felt there was no need to cite their previous unpublished works, while approximately $80 \%$ of faculty considered this to be self-plagiarism. Some recommendations on ways for faculty and administrators to handle self-plagiarism are discussed, as well as the need to have a specific institutional policies and procedures that address this issue in place. Faculty are becoming more aware of this issue as the use of plagiarism detection programs increase.
\end{abstract}

Keywords: Self-plagiarism, Student recycling, Academic honesty, Faculty perceptions, Student perceptions

\section{Introduction}

What exactly is self-plagiarism? Many faculty and students are not sure; however, they view the recycling of assignments very differently. Some faculty members want students to create a completely new product for their classes, while the students tend to view their work as unpublished and consider recycling parts of previous assignments as effective use of their time. Students also tend to think of plagiarism only as copying the work of others without citing the author. They do not consider copying sentences or phrases they have written before as a type of plagiarism. Who is correct? The answer to this question depends on the education institution and solutions need to be found to address this disconnect in student and faculty perceptions and expectations.

I first became interested in the issue of self-plagiarism two years ago when I supervised online adjunct faculty for multiple degree programs at a small private university. I handled all of the student grade appeals and plagiarism reporting for all online programs. One day a faculty member contacted me to report plagiarism on a student who had used a paragraph from a paper she had done in a previous class as part of a longer essay in his class. The recycled piece was the student's own work, but he insisted on giving her a zero on the paper because the university policy for the first incident of plagiarism was to award a zero. The student filed an appeal. My first instinct was this was not truly plagiarism; instead, this was a different issue of academic honesty that was not addressed in our policy. I looked back on my own practices as a student. When I was obtaining my own doctorate degree, I tried to link as many assignments as possible to my dissertation literature review topic so I could have most of it done by the time I was ready to draft my dissertation proposal and literature review chapter. There was the possibility I had recycled a sentence or two on the way in trying to do this. Did this make me unethical? I did not think so; in fact, at the time a lot of professors and fellow students had commented to me that it was smart use of my time. It enabled me to gather a large amount of data over a period of time and served a dual purpose. Plagiarism to me when I was a student was when you copied someone else's work and claimed it as your own. The difference between now and over a decade ago is technology in the form of plagiarism detection programs has allowed recycling of partial pieces of unpublished student work to be detected. Over one million faculty are using just the Turnitin program (Turnitin, 2014). This has redefined the definitions and conditions of plagiarism. 


\section{How Faculty Perceive Self-Plagiarism}

The first thing I did two years ago when presented with this issue was to go to the literature to see if there was any indication that self-plagiarizing was actually possible or defined. There was very little in the literature on this topic. I found one scholarly research article by Bennett, Behrendt and Boothby which was a small study of psychology faculty written in 2011. Bennett et al. found faculty opinions were split regarding self-plagiarism: $54 \%$ thought recycling of assignments was self-plagiarism, while $46 \%$ were neutral or did not think it was self-plagiarism. Lang (2010) who addressed this issue thematically and not in a research capacity, noted students cannot truly plagiarize their own work because it is not published; in fact, because it already has been graded, it has been previously validated. Otherwise, there was only literature on plagiarism of others' work and faculty self-plagiarism regarding multiple submissions of the same research study to multiple publications. So, at this point I made a decision about the case that had been reported to me. I opted for somewhat of a compromise where I ruled the case was not plagiarism by the university definition; however, it was academic dishonesty because it was not original work for the class. Therefore, instead of getting a zero on the assignment the student would get a reduction in points instead. My thought process was this would be fair as possible to the students and the instructor since neither the university nor the instructor had communicated to the students a specific policy about recycling of work. I also let administration know a self-plagiarism policy was needed. However, this particular incident sent me on a quest to see what students and faculty felt about this issue at this university and at two other university campuses I am affiliated with.

Within a year of this incident, I started a multi-university study on faculty attitudes towards self-plagiarism or student recycling of previous assignments with a colleague. In completing the literature review, we also found some additional information in the literature I had not found previously. In 2002, Bird noted self-plagiarism is not possible since the work is not copyrighted. In 2010, Walker called the resubmission of the same assignment for multiple classes as a type of plagiarism. This specifically referred to a paper reused "in total" rather than recycling just random paragraphs or sentences of previous unpublished work. Syed-Brown in 2010 also echoed Walker's opinion, but did not differentiate between whole papers and excerpts from a previous paper. The Roosevelt University's Editorial Board in 2007 noted if a student submits the same assignment for two different classes (even if it meets the criteria), this would result in a zero on the assignment; however, the board noted that even with this as university policy, both faculty and students are ambivalent about self-plagiarism. This ambivalence can lead to the policy being ignored. The Board goes on to note if the university curriculum has such duplication in it, this is in fact a type of self-plagiarism. If faculty expect original work from students, then faculty must coordinate to provide original curriculum for the students.

In 2013 I published, along with my colleague Doris Bolliger, a multi-university exploratory study of faculty perceptions of self-plagiarism that looked at multiple aspects of how faculty viewed their students' actions, their own actions as students and their own actions as scholarly professionals. We queried all faculty, (including adjuncts) at a small private university with a very large engineering program and two campuses (one in Arizona and one in Missouri) at a graduate health sciences university that included two medical schools, two dental schools and additional programs in health sciences and health management; faculty from 27 disciplines were included in the population. The faculty at these universities had taught an average of 14 years. The faculty members at these institutions reported self-plagiarism was not well understood by students $(\alpha=1.89$ on a 5.0 Likert scale) or faculty $(\alpha-2.91)$. Over $86 \%$ of the faculty felt obligated to follow university plagiarism policies because they consider themselves role models for their students. This perception of obligation can be problematic if university policies are not well-defined and clearly stated. When asked if they perceive reuse of a portion of a previous assignment as self-plagiarism, almost $66 \%$ said it was; $80 \%$ perceived students to have committed self-plagiarism if they reused an entire paper they had written previously in another class. In addition, almost $71 \%$ felt students should ask permission of an instructor to reuse their own unpublished work in a different assignment. Since neither institution had a self-plagiarism policy in place at the time, faculty were queried if they informed students of their own policies about self plagiarism; only 13\% did so (Halupa \& Bolliger, 2013).

After our research on faculty perceptions was written and accepted, the Office of Research Integrity in May 2013 placed the following information regarding self-plagiarism on their website:

Redundant publication has a direct counterpart in the area of academic dishonesty- it is

referred to as 'double dipping'. It occurs when a student submits a whole paper or a

substantial portion of a paper to fulfill a course requirement, even though that paper had

earlier been submitted to satisfy the requirements for another course taught by a different 
professor. Many college undergraduates and even some graduate students are not aware that this type of practice is a serious offense and constitutes plagiarism. Of course, as in redundant publication, submitting the same paper, or a large portion of a paper, to two different courses is entirely acceptable if the instructors of both courses were informed by the student of the double submission, and if both agreed to the arrangement. However, some institutions have specific policies prohibiting this practice (p. 1).

After we completed data collection on faculty attitudes, we decided to look at student perceptions as well. We began this study in October 2013.

\section{How Students Perceive Self-Plagiarism}

There are several researchers who say or allude to the fact students feel differently about recycling assignments than faculty do, but there is nothing really definitive on how different. In 2003, Park noted students can differentiate serious cheating (such as buying a research paper) as wrong, but often do not view lesser offenses (such as recycling of assignments) as cheating. In 2005, Jones, Reid and Bartlett noted practices regarding plagiarism and academic honesty are not considered to be dishonest by many students. Jones et al. referred to self-plagiarism as replication and consider it to be a practice that constitutes cheating, but found almost half (48.4\%) of students viewed it as acceptable if teachers give assignments that can be recycled. Owunwanne, Rustagi, and Dada (2010) reported only $38 \%$ of students they surveyed considered self-plagiarism as cheating.

In 2008 Maxwell, Curtis and Vardenega queried 267 Australian and Asian students at an Australian University. Only $8 \%$ of the 152 Australian students and $22 \%$ of the 112 Asian students viewed recycling of student assignments as a form of plagiarism. In addition, it was the least recognized of seven forms of plagiarism identified in the research study. All of these students rated recycling as only a slightly serious offense.

Sweet-Holp and James (2013) queried 471 students at a historically black college about academic honesty using a scale created by Hard, Conway and Moran (2006) whose research was done at a predominantly white university. Students were asked to rate the following, "Submitting the same work, or substantially similar work, in more than one course without prior consent of the evaluating instructors" with varying degrees of acceptability. Only $41.4 \%$ students viewed this as completely unacceptable. In addition, the mean scores showed the students overall reported recycling work occasionally.

My colleague and I have finished data collection on the corresponding study of students' perceptions of self-plagiarism at the same three university campuses where we previously assessed the faculty. I knew this second part of the research would result in a dichotomy in findings as soon as I sent out the link to the survey to the students. Every time I have done research I have always included a sentence in the informed consent that if a participant wanted copies of the final results to please contact me. I have never had anyone take me up on it. The day I sent the survey out to the same university where I got the original ideal to study this concept, I had no less than nine participants ask me to please give them a copy of the research when I was done. Since the message was sent out in two parts (residential students first and then online students), I had two students email me right after the request went out to ask me where their message was since they were anxious to provide their opinions. One told me he had reeived a zero on an assignment because he had used a paragraph from a previous paper that had been identified on the SafeAssign plagiarism detection program. Another few had a problem getting into the survey site and asked me for assistance since they absolutely wanted to participate. This also has never happened to me before; instead of begging participants to do my surveys, they were asking me to please ensure they could be heard.

We have just completed data collection and are currently doing analysis. We hope to add to the body of literature regarding how students view the issue of self-plagiarism. We plan to compare the student perceptions to the corresponding faculty perceptions in our previous study and hope to publish this student perception study in its entirety in the future. However, some of the preliminary descriptive statistics have proved interesting so far. We had a response from 250 students for a return rate of approximately 17\%. No student incentives to participate were offered.

Many of the student's perceptions mirror the perceptions of the faculty, but there are some key areas where disconnects occur. First, only about $37.2 \%$ of the student respondents think self-plagiarism is a clearly defined concept; this mirrors almost exactly the faculty finding of $38.2 \%$. What this means clearly is over $60 \%$ of students and faculty truly do not understand what self-plagiarism is or how it should be handled. In addition, students had a 
more optimistic view of their instructor's understanding of self-plagiarism; almost $50 \%$ of students felt their professors understood it, while only about $36 \%$ of the faculty reported understanding the concept.

About $32 \%$ of the students queried had recycled parts of previous assignments into new ones with another $7 \%$ indicating they were not sure. This represents a significant number of students who have recycled work. Twenty-three percent of the students indicated they had been encouraged by one or more faculty members to do this in the past. This does not necessarily mean faculty were encouraging the students to self-plagiarize; instead it could mean faculty have designed courses where assignments build upon one another to create a total product such as a project or portfolio, or multiple drafts of an assignment were required to be submitted for a class. About $40 \%$ indicated all of their assignments in the past were completely original work which infers these students were either self-plagiarizing from their own previous work or plagiarizing from other's work. Over $43 \%$ of students felt there was no need to cite their own previously unpublished works, while another $18.3 \%$ were neutral or did not know; this totals over $60 \%$. However, the majority of the faculty regarded this as self-plagiarism. This is an area of definitive differences in student and faculty perceptions. Perhaps the largest area of disagreement between faculty and students regarding self-plagiarism is in regards to the reporting of self-plagiarism to the university; only $23.4 \%$ or students compared to almost $60 \%$ of faculty felt all cases should be reported.

Although $40 \%$ of faculty wanted students to "cite themselves" if they used a sentence or more from a previously unpublished assignment, only $20 \%$ of the students reported ever doing so. This is an additional area where a disconnect has occurred between student and faculty perceptions. Only $47.6 \%$ of students felt they were self-plagiarizing if they did not ask instructor permission to use parts of previous works, while $70.6 \%$ of faculty considered this self-plagiarism. This is a second area of differences in student and faculty perceptions. Even more concerning is well over half of the students were graduate students who had been in the academic environment more than four years; they were not novice students or writers. The mean student age was over 29 years.

\section{Potential Solutions}

Back in 1997, Roig called for specific, accurate definitions of academic dishonesty, yet today over 15 years later, higher education has really not dealt with this issue consistently. Every university has different academic honesty policies and rules and there is no standard in regards to the unacceptability of various scenarios. Policies tend to be generalized rather than specific which leads to faculty subjectivity. This, in turn, can lead to additional student confusion when facult interpret policy differently at different or even at the same universities.

In 2005 McCabe noted policies for academic honesty, as well as honor codes, were effective to reduce cheating in a previous study population of over 15,000 students; however, he noted these cannot only be the only measures used. The most significant influence was students' perception of their peers' behavior. Another factor was student's perception of teaching quality; students reported they were more likely to cheat if the professor provided unclear or poor assignments. Looking at McCabe's findings almost a decade later, if peer pressure is critical, students may be less likely to cheat (including self-plagiarism if it is considered an academic honesty offense) if there is a clear and easy to use reporting system that is used consistently by faculty. When academic dishonesty is reported and dealt with through education and discipline as appropriate, students are likely to discover the university is serious about the issue.

Many of the larger U.S. universities have not addressed the issue of self-plagiarism in their academic honesty policies published online. As of January 2014, this includes Stanford University (2014), Purdue University (2014), the University of Tennessee (2014), The University of Massachusetts at Amherst (2014) and others.

Some schools have been forward-thinking and have addressed the issue of self-plagiarism very clearly. At Harvard, the John F. Kennedy School of Government (2014) does include self-plagiarism in their academic honesty policy. The phrasing of their policy is as follows:

All work submitted to meet course requirements should be original work by the student for the specified assignment. It is not acceptable to submit work from a previous assignment for a current assignment. A student who submits the same paper in substance for more than one course at the Kennedy School or for any other course without prior written permission of the instructors is in violation of the Academic Code.

Students may continue their investigations of specific topics by incorporating previous research.

In that case the student should speak with the instructor to ensure that the work is incorporated appropriately 
(p. 1).

Yale University has also addressed student self-plagiarism in their policies, "Any form of academic dishonesty, whether it be cheating on a test or an examination, plagiarism, improper collaborating on assignments, or the submission of the same essay to two instructors without the explicit consent of both, should be reported to the secretary of the Yale College Executive Committee" (2014, p. 1). The University of Texas at Austin also addresses this issue, “'academic dishonesty' or 'scholastic dishonesty' includes, but is not limited to, cheating, plagiarism, collusion, falsifying academic records, misrepresenting facts, and any act designed to give unfair academic advantage to the student (such as, but not limited to, submission of essentially the same written assignment for two classes without the prior permission of the instructor), or the attempt to commit such an act." (2014, p. 1).

\section{Discussion, Reflection and Conclusions}

Looking back my "student self-plagiarism" journey over the last two years, the most critical current issue related to this topic is the fact faculty and students view self-plagiarism differently. Definitive institutional and/or instructional written policies and procedures to ensure compliance with these policies are greatly needed to bridge this divide. Without such measures, students grades will suffer because many students will think self-plagiarism is an acceptable practice; in addition, they will potentially be frustrated (and "vote with their feet" in course evaluations) by faculty who do not let them know of their expectations in this regard.

The governmental and other pressures higher education is facing are more significant than ever. Universities are being called upon to prove they do what they say they do and provide a high quality education at a lower cost. This accountability includes maximizing student success and retention. Having clear academic honesty policies and processes, including those for self plagiarism, that are understood clearly by students and faculty alike is an important step on the road to attaining these goals.

Faculty are also becoming more aware of the issue of self-plagiarism and are seeking guidance on how to deal with it. Institutions need to be aware of the differences in the way faculty and students view this issue. This awareness can eventually lead to a call for creation of policies and procedures that are definitive with clearly delinated expectations for both faculty and students.

\section{Acknowledgements}

I would like to acknowledge my friend, colleague, and research partner Dr. Doris Bolliger who collaborated with me on both studies examining perceptions of self-plagiarism.

\section{References}

Bennett, K. K., Behrendt, L. S., \& Boothby, J. L. (2011). Instructor perceptions of plagiarism: Are we finding common ground? Teaching of Psychology, 38(1), 29-35. http://dx.doi.org/10.1177/0098628310390851

Bird, S. (2002). Self-plagiarism and dual and redundant publications: What is the problem? Science and Engineering Ethics, 8, (4,) 543-544. http://dx.doi.org/10.1007/s11948-002-0007-4

Editorial Board. (2009,,November 22). Is self-plagiarism academically dishonest? [Online] Available: http://www.roosevelttorch.com/2.14124/is-self-plagiarism-academically-1.1955346

Halupa, C. \& Bolliger, D. U. (2013, December). Faculty perceptions of student self-plagiarism: An exploratory multi-universitystude, Journal of Academic Ethics, 11( 4), 297-310. doi 10.1007/s10805-013-9195-6

Hard, S. F., Conway, J. M., \& Moran, A. C. (2006). Faculty and college student beliefs about the frequency of student academic misconduct. The Journal of Higher Education, 77,(6) 1058-1080. http://dx.doi.org/10.1353/jhe.2006.0048

Harvard Kennedy School of Government (2014) Academic code version 2.0. [Online] Available: http://www.hks.harvard.edu/var/ezp_site/storage/fckeditor/file/pdfs/degree-programs/registrar/academic_code.p df

Jones, K. O., Reid, M.V \& Bartlett, R. (2005). Student plagiarism and cheating in an IT age. International Conference on Computer Systems and Technology Proceedings, 8-1-8.6.

Lang, J. M. (2010, October 4). Plagiarizing yourself. The Chronicle of Higher Education. [Online] Available: http://chronicle.com/article/Plagiarizing-Yourself/124781/

Maxwell, A., Curtis, G. J \&Vardenega, L. (2008, December). Does culture influence understanding and perceived seriousness of plagiarism. International Journal for Educational Integrity, 4 (2) 25-40. 
McCabe, D. (2005). Cheating among college and university students: A North American perspective. International Journal for Educational Integrity, 1, 1. http://dx.doi.org/10.1111/j.1475-682X.1992.tb00287.x

Office of Research Integrity (2013,May). Academic self-plagiarism: Double dipping. [Online] Available: http://ori.hhs.gov/plagiarism-15

Owunwanne, D., Rustagi, N., \& Dada, R. (2010). Students' perception of cheating in higher education institutions. Journal of College Teaching and Learning, 7,(11) 59-68.

Park, C. (2003). In other people's words: Plagiarism by university students, literature and lessons. Assessment and Evaluation in Higher Education, 28, 5, 471-488. http://dx.doi.org/10.1080/02602930301677

Purdue University. (2014). Academic integrity: A guide for students. [Online] Available: http://www.purdue.edu/odos/osrr/academicintegritybrochure.php

Roig, M. (2011, September 28). Avoiding plagiarism, self-plagiarism, and other questionable writing practices: A guide to ethical writing. [Online] Available: http://ori.dhhs.gov/sites/default/files/plagiarism.pdf

Stanford University. (2014). Honor Code. Retrieved at http://studentaffairs.stanford.edu/communitystandards/policy/honor-code

Sweet-Holp T. J. \& James, V. M. (2013). Academic misconduct: Student beliefs and behaviors at HBCU. The Online Journal of New Horizons in Education, 3 (4) 1-11.

Syed-Brown, C. (2010). Did I say that? Thoughts on self-plagiarism. Library and Archival Security, 23(2), 137-139. http://dx.doi.org/10.1080/01960075.2010.522899

Turnitin. (2014). FAQs. [Online] Available: http://turnitin.com/en_us/features/faqs

University of Massachusetts at Amherst. (2014). Academic honesty and appeal procedure. Sen Doc 07.040A. [Online] Available: http://www.umass.edu/dean_students/downloads/AcademicHonestyPolicy.pdf

University of Tennessee. (2014). Academic policies and procedures. [Online] Available: http://catalog.utk.edu/content.php? catoid=1\&navoid=156\#hono_stat

University of Texas at Austin. (2014). Course Catalog Chapter 11, Sec. 11-402. [Online] Available: $\mathrm{http} / / /$ catalog.utexas.edu/general-information/appendices/appendix-c/student-discipline-and-conduct/

Walker (2010). Measuring plagiarism: Researching what students do, not what they say they do. Studies in HigherEducation, 3 ( 1) 41-59. http://dx.doi.org/10.1080/03075070902912994

Yale University. (2014). Academic Dishonesty. Instructor Handbook. [Online] Available: http://yalecollege.yale.edu/content/academic-dishonesty 